\title{
A skull fragment of a Devonian tetrapod with a unique lateral line morphology in the collection of the Museum für Naturkunde Berlin
}

\author{
Florian Witzmann
}

Museum für Naturkunde Berlin, Invalidenstraße 43, 10115 Berlin, Germany. E-mail: florian.witzmann@mfn-berlin.de

Received 1 May 2009

Accepted 16 October 2009

Published 3 August 2010

\section{Key Words}

Dermal sculpture

Ketleri

Latvia

postorbital

Venta river

Walter Gross

\begin{abstract}
A dermal bone from the late Famennian of Ketleri in Latvia, identified as a probable tetrapod postorbital by Oleg Lebedev and stored in the Museum für Naturkunde Berlin, is described in detail. Its tetrapod status is confirmed based on the dermal sculpture consisting of polygonal pits and radially aligned ridges and furrows. The sculpture resembles that of Devonian tetrapods but is nevertheless not as regular as in most postDevonian forms. The bone can be designated as a postorbital because of its concave anterior margin, the lateral line that shows no bifurcation, and the ossification centre that is located in the dorsal portion of the bone. The lateral line (i.e., the postorbital branch of the infraorbital line) forms an open, deep sulcus in the ventral portion of the postorbital but is enclosed within the bone in the dorsal portion and opens through pores to the surface. This morphology of the postorbital branch is unique among basal tetrapods. The bone might belong to the tetrapod Ventastega curonica Ahlberg et al., 1994 that is known from the same strata at Ketleri, however, since the postorbital is unknown in this taxon, this cannot be stated with certainty.
\end{abstract}

\section{Introduction}

In the original description of the Devonian tetrapod Ventastega curonica Ahlberg et al., 1994, Oleg Lebedev mentioned his finding of an uncatalogued, presumed postorbital bone from the Late Devonian of Latvia in the collection of fossil fishes in the Museum für Naturkunde in Berlin (Ahlberg et al. 1994). The bone bears a dermal sculpture of radially arranged ridges and furrows and is crossed by a partially enclosed lateral line canal. This specimen was collected at the right bank of the Venta river (former German name: Fluss Windau) near Ketleri hamlet by Walter Gross in 1931 together with a large amount of further vertebrate remains. Two years later, Gross (1933) described several of his findings that mainly consisted of 'agnathans', placoderms, chondrichthyans, actinopterygians and fish-like sarcopterygians. However, he neither described nor mentioned the postorbital bone from Ketleri. Ahlberg et al. (1994) gave a brief description of this bone, but did not provide an illustration. Based on the 'tetrapod-like' dermal sculpture of this bone, these authors suspected that it probably belongs to a tetrapod, possibly to Ventastega, remains of which have also been found at Ketleri locality. Because of the uncertainty of its taxonomic affinities,
Ahlberg et al. (1994) did not incorporate this bone in their reconstruction of the skull of Ventastega.

The Ketleri Formation, from which this bone is derived, is late Famennian (Late Devonian) in age. It is composed of unconsolidated sand, sandstones, clays and dolomitic marls, and was probably deposited in a shallow basin under brackish conditions (Lukševičs \& Župins 2004). Lyarskaja \& Savvaitova (1974) divided the Ketleri Formation into three members with the Ketleri locality belonging to the upper member, which is named Varkali Member. A diverse vertebrate fauna has been excavated at the Venta river near Ketleri (Gross 1933; Lukševičs 1991, 2001; Ahlberg et al. 1994) that comprises the placoderm Bothriolepis ciecere Lyarskaja, 1974 (in Lyarskaja \& Savvaitova 1974), the acanthodians Devononchus tenuispinus (Gross, 1933) and D. ketleriensis Gross, 1947, the porolepiform Holoptychius cf. nobilissimus Agassiz, 1839, the osteolepiforms Cryptolepis grossi Vorobyeva, 1975 and Glyptopomus bystrowi (Gross, 1941), the dipnoan Orlovichthys cf. limnatis Krupina, 1980, the enigmatic Ventalepis ketleriensis Schultze, 1980, which is a possible holoptychiid (Schultze 1980), and the tetrapod Ventastega curonica. Ahlberg et al. (1994) pointed out that a large tristichopterid (eusthenopterid) probably also belongs to the fauna at Ketleri site. 
Since the first mentioning of the postorbital bone from Ketleri by Ahlberg et al. (1994), the specimen has got an inventory number but was not assigned to any vertebrate group. The present study gives a detailed description of this element for the first time and aims to assess the characters that justify its tetrapod nature.

In the present paper, the apomorphy-based definition of Tetrapoda is used, i.e., Tetrapoda is defined as a clade that encompasses those vertebrates, which have digitized limbs rather than paired fins (see Anderson 2002, and references therein). This apomorphy-based definition considers the historical usage of the term Tetrapoda and reflects its etymological meaning. An apomorphy-based Tetrapoda is monophyletic and the homology of its key-apomorphy, the limb with digitized manus and pes, has been demonstrated (J. S. Anderson in Laurin \& Anderson 2002). In contrast, a phylogenetic definition of Tetrapoda would either exclude several fossil taxa, which definitively possess digitized limbs (crown-group definition), or would include many sarcopterygians, which possess fins rather than limbs (total-group definition). A further challenge of the phylogenetic definition of Tetrapoda is that there is still no consensus concerning the composition of the tetrapod crowngroup and the identity of the living sistergroup of Tetrapoda (Ahlberg \& Clack 1998, and references therein).

\section{Material}

The specimen is stored under inventory number MB.f.18028 in the collection for fossil fishes of the Museum für Naturkunde Berlin and consists of an isolated dermal bone fragment, which is almost completely freed from the surrounding sediment matrix. Attached remnants of the bright sandstone can be found only in some of the pits of the sculptured external bone surface.

\section{Description of MB.f.18028}

In the following description, the anatomical terms of location (dorsal, ventral, anterior, posterior) refer to the interpretation that this bone is a right postorbital (see discussion). This applies also to the names of the presumed neighbouring bones of this element. The specimen is a flattened dermal bone of elongate, quadrangular outline with a gently tapering ventral margin (Figs 1, 2). It measures $34 \mathrm{~mm}$ in dorsoventral extension and has a maximum antero-posterior length of $18 \mathrm{~mm}$. In its dorsal portion, the thickness of the bone reaches its maximum of $4.5 \mathrm{~mm}$, whereas it thins out in a ventral direction where it measures slightly less than $2 \mathrm{~mm}$ in its thinnest part. An exception is the anterior (i.e., orbital) margin, that almost retains its thickness also in the ventral portion of the bone. The orbital margin is well preserved. At most of its length, it is rather straight; in its dorsal portion, it turns abruptly in an anterior direction, whereas in the ventral part, the anterior curvature proceeds more gently. Thus, the concave orbital margin appears somewhat angled rather than evenly rounded. The thickened dorsal margin of the bone is straight in its anterior two thirds, before it slopes slightly posteroventrally. The anterior two thirds of the margin probably formed a suture with the postfrontal, whereas the posterior portion might have sutured with an intertemporal or a supratemporal. At least the anterior portion of the dorsal margin exhibits no sutural interdigitations, but a shallow furrow runs antero-posteriorly on the edge, as already recognized by Ahlberg et al. (1994). Thus, the sutural connection with the adjacent dorsal bone (probably the postfrontal) must have been rather straight, and Ahlberg et al. (1994) did not rule out that the dorsal suture might have been kinetic. The original posterior margin of the bone is not preserved since the posterior portion has broken off, so that the specimen is delimited posteriorly by a rather straight edge. The ventral margin of the bone is slightly abraded, but probably corresponds to the original suture with the ventrally attaching bone (presumably the jugal).

The external (superficial) surface of the bone is conspicuously sculptured by ridges, pits, and furrows. Mainly polygonal pits enclosed by ridges can be found in the posterodorsal region, from which ridges and elongate pits and grooves radiate and are directed anteroventrally and ventrally (Figs 1A, 2A). According to Bystrow (1935), the region of a dermal bone with polygonal sculpture usually represents its ossification centre, which in specimen MB.f.18028 is therefore located in its posterodorsal portion. This centre, however, is not completely preserved since the posterior break runs right through it. Overall, the dermal sculpture of the bone appears rather irregular because the pits differ conspicuously in size and shape, and the sculptural ridges and their 'nodal points' (i.e., the points of intersection in which the sculptural ridges meet) show great variability in height and width. The ridges may be broadly rounded or sharply edged dorsally. Each pit contains at least one vascular opening (i.e., the opening of a large vascular canal) on its bottom. As common in sculptured dermal bones of basal tetrapods (Witzmann et al. in press), these canals are directed approximately perpendicular to the bone surface in the polygonal pits of the ossification centre, but are directed obliquely to the surface and aligned rather parallel to the anteroventrally and ventrally running sculptural ridges of the more ventral region. Apart from these vascular openings, there are numerous tiny pores distributed all over the bone surface, both in the pits and furrows, and on the sculptural ridges. In temnospondyls, Bystrow (1935) associated such pores on the dermal sculpture with a network of capillaries within the bone, which he designated as the 'Rete vasculosum'. Whereas the external surface is rather plane in the dorsal half of the bone, it is slightly concave in its ventral half. This concave area is delimited anteriorly by the open lateral line sulcus (see below) and the thickened orbital margin. 
Figure 1. Right postorbital of an unidentified tetrapod from the late Famennian (Late Devonian) of Ketleri, Latvia, stored in the Museum für Naturkunde Berlin under inventory number MB.f.18028. A. External view; B. Internal view.

Figure 2. Drawing of right postorbital MB.f.18028 from the late Famennian (Late Devonian) of Ketleri, Latvia. A. External view; B. Internal view.
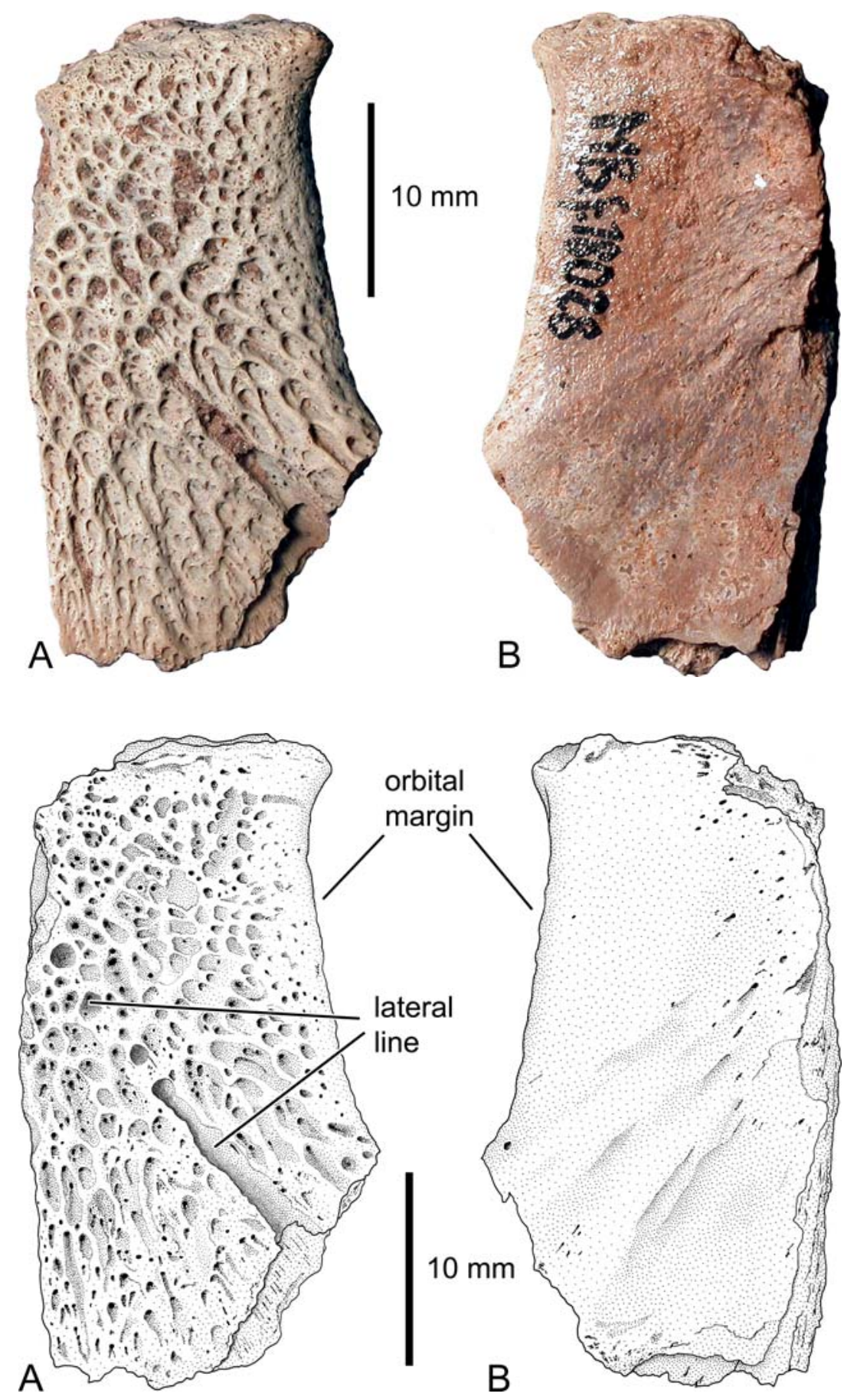

A straight, deeply impressed lateral line sulcus is present in the ventral portion of the bone that runs from its anteroventral edge, close to the orbital margin, in a posterodorsal direction (Figs 1A, 2A). Where the infilling of sandstone matrix is removed, it is visible that the bottom of the sulcus is smooth. After approximately $10 \mathrm{~mm}$, the sulcus narrows before it ends after $2 \mathrm{~mm}$ in a circular foramen that has a diameter of about $1 \mathrm{~mm}$. Three further foramina can be discerned and are aligned in a row, forming the posterodorsal continuation of the sulcus. These foramina can be differentiated from pits of the dermal sculpture by their more rounded shape.
The internal (deep) surface of the bone is mostly smooth (Figs 1B, 2B). Several vascular canals open to the surface in the posterodorsal portion and are directed anteroventrally and ventrally. In this region, the bone surface shows a gentle upturn that constitutes approximately the dorsal half of the posterior portion.

\section{Discussion}

\section{Identification of the bone}

Ahlberg et al. (1994) suggested that the bone under study probably represents a postorbital but did not dis- 
cuss this issue any further. The postorbital interpretation is followed here. The lateral line canal does not bifurcate, which renders an identification as a jugal implausible. Also the location of the ossification centre of the bone as indicated by the pattern of dermal sculpture, supports the assignment of the bone as a postorbital. The ossification centre is located at one end of the bone (interpreted here as the dorsal portion), from which the radially arranged sculpture fans out. A similar pattern was described in the isolated postorbital of an undetermined tetrapod (?Tulerpeton) from Devonian rocks of the Tula Region, Russia (Lebedev \& Clack 1993), and in the same bone of an undetermined Devonian tetrapod from Red Hill, Pennsylvania, USA (Daeschler et al. 2009, fig. 5a). In Acanthostega, the polygonal sculpture is likewise confined to the dorsal portion of the postorbital (Clack 2003, fig. 1). In contrast, if the bone under study represented a jugal, the ossification centre with polygonal pits would be located more at mid-length along the orbital margin and send out radial furrows and ridges towards both ends. Furthermore, the bone from Ketleri is similar to the postorbital from Tula Region in that the bone is thickened dorsally and becomes thinner in ventral direction. Also, the suture with the postfrontal is similarly smooth in the Tula specimen and might be associated with a kinetic junction between the cheek and the skull table (Lebedev \& Clack 1993).

\section{Tetrapod nature of the bone}

Ahlberg et al. (1994) stated that the dermal bone from Ketleri probably belongs to a tetrapod based on the tetrapod-type dermal sculpture. This assumption is followed here. Godfrey (1989, p. 127) considered dermal sculpture that 'consists of deep polygonal pits or troughs surrounded by raised ridges' as a tetrapod autapomorphy, and this type of sculpture is found on the external surface of the bone under study. Its irregular sculptural pattern closely resembles that of Ventastega and the undetermined Devonian tetrapod from Tula (personal observations). In contrast, the sculptural pattern of most post-Devonian tetrapods like temnospondyls or seymouriamorphs is more regular in that the shape and size of the pits and the height and width of the sculptural ridges generally do not show a correspondingly broad variation (Witzmann et al. in press). Unlike the studied bone, the fish-like sarcopterygians that co-occur in Ketleri, i.e., the porolepiform Holoptychius (Jarvik 1972), the 'osteolepid' Glyptopomus bystrowi (Gross 1941; Vorobyeva 1962), and tristichopterids (Jarvik 1944) have a tubercular or vermiculate dermal sculpture. The osteolepiform Cryptolepis grossi, which was also found at Ketleri site, has cosmine-covered dermal bones (Vorobyeva 1975). Furthermore, in porolepiforms (Jarvik 1972) and osteolepiforms (Jarvik 1944), the lateral lines, which are enclosed in bone, have numerous side branches, whereas in tetrapods, the enclosed canals open via unbranching tubes to the bone surface (Säve-Söderbergh 1932). No side branches are visible in the lateral line of the bone under study. Its tetrapod assignment is further supported by the gentle curvature of the orbital margin that indicates a proportionally large orbit, which is typical for early tetrapods (Coates \& Clack 1995; Ahlberg 1998).

\section{Lateral line}

In most early tetrapods, the lateral line organ was located at least partially in open sulci on the surface of dermal skull bones, whereas in their fish-like relatives, they ran in true canals within the bone and opened to the surface through pores (Clack 2002a). If the interpretation is correct that the bone from Ketleri is a postorbital, then the lateral line canal represents the postorbital part of the infraorbital line. It consists of an open, but deep sulcus in the ventral portion of the bone and continues in the dorsal part as a row of pores (three single pores and one pore at the termination of the sulcus; see Figs 1A, 2A). In Devonian tetrapods from which the postorbital is known, the openings of the postorbital lateral line are restricted to the ventral portion of the bone, either as a continuous sulcus or as a row of pores (Fig. 3). However, the line may continue as a closed canal to the dorsal edge of the bone (Jarvik 1996; Ahlberg 1998). In Acanthostega and Greererpeton, the postorbital line is developed as an open sulcus in the more ventral part of the postorbital similar to the Ketleri specimen (Figs 3E, F); this is also the case in the isolated postorbital from Red Hill. However, the line ends in the region of the ossification centre in these taxa (Clack 2002b; Smithson 1982; Daeschler et al. 2009). The isolated tetrapod postorbital bone from the Late Devonian of Scat Craig in Scotland has a lateral line that is enclosed within the bone (Ahlberg 1998). It opens via pores to the surface in the ventral portion (Fig. 3C), but is completely closed in the dorsal part and is visible as a large opening on the dorsal edge of the bone. A similar situation is present in Ichthyostega (Fig. 3B; Säve-Söderbergh 1932). The postorbital from Ketleri is unique among Devonian tetrapods because its lateral line continues in the dorsal portion as an enclosed canal plus pores (Fig. 3D). In contrast to tetrapods, the postorbital line is enclosed in bone in the fish-like sarcopterygians Panderichthys (Vorobyeva \& Schultze 1991) and Tiktaalik (Fig. 3A; Daeschler et al. 2006), and is visible on the bone surface both on the dorsal and ventral portion as a sensory pore line. Therefore, the pores on the dorsal portion of the Ketleri specimen might be interpreted as a plesiomorphic character. However, the presence of an open lateral line sulcus in the Ketleri specimen is a character that is more 'tetrapod-like' than the enclosed lines of Ichthyostega (Säve-Söderbergh 1932). 
Figure 3. Schematic drawings of postorbitals in early tetrapods and Tiktaalik, not to scale. The lateral line sulci and pores, respectively, are held in dark grey. The orbital margin (i.e. anterior) is on the right; to facilitate comparisons, drawings $\mathrm{A}$ and $\mathrm{C}$ are reversed. A. Tiktaalik, a Late Devonian tetrapodomorph fish (after Daeschler et al. 2006); B. Ichthyostega, a Late Devonian tetrapod (after Säve-Söderbergh 1932); C. Tetrapod postorbital fragment from the Late Devonian of Scat Craig, Scotland (after Ahlberg 1998); D. Ketleri postorbital; E. Acanthostega, a Late Devonian tetrapod (after Clack 2003); F. Greererpeton, an Early Carboniferous tetrapod (after Smithson 1982).

\section{Conclusions}

The following characters identify the bone from Ketleri as a tetrapod dermal bone: (1) the tetrapod-type dermal sculpture on the external bone surface; (2) the lateral line is partially developed as an open sulcus, and the enclosed portion opens via unbranching tubes to the bone surface; (3) the gentle curvature of the orbital margin suggests a proportionally large orbit as common in early tetrapods, in contrast to the proportionally smaller orbits of fishlike sarcopterygians. This dermal bone can be assigned as a postorbital and not as a jugal for the following reasons: (1) the lateral line canal does not bifurcate; (2) the ossification centre is located at one end of the bone. The lateral line morphology of this postorbital differs from that of all other known early tetrapods in that it consists of an open sulcus in one portion of the bone, whereas it is enclosed in the other portion and opens to the bone surface via pores. As suggested by Ahlberg et al. (1994), this specimen could belong to the Devonian tetrapod Ventastega curonica, which has been found in the Ketleri Formation both at Ketleri and Pavāri on the Ciecere River in Latvia. This assignment cannot be stated with certainty since a postorbital that can definitively be attributed to Ventastega, has not been found so far (Ahlberg et al. 1994, 2008). Interestingly, Ahlberg et al. (1994) reported an isolated fragment of a lower jaw from Ketleri, which probably belongs to a second tetrapod taxon, indicating that at least two tetrapods were present in the Ketleri fauna. Thus the postorbital from Ketleri is most suitably described as an undetermined Devonian tetrapod.

\section{Acknowledgements}

I want to thank Oleg Lebedev (Paleontological Institute, Moscow) and Ivars Zupiņš (Latvian Museum of Natural History, Riga) for access to the collections of Ventastega and other Devonian vertebrates under their care. The reviews of Nadia Fröbisch (Chicago), Marcello
Ruta (Bristol), Rainer Schoch (Stuttgart), and Hans-Peter Schultze (Lawrence) helped to improve the manuscript. Henning Scholz (Berlin) is acknowledged for taking the photographs, and Johannes Müller (Berlin) for helpful comments on the manuscript. The Deutsche Forschungsgemeinschaft is thanked for financial support (DFG-grant "Dermal bone sculpture in basal tetrapods").

\section{References}

Agassiz, L. 1839. Fishes of the Upper Ludlow Rock. In Murchison, R. I. (ed.). The Silurian System. Vol. 2. John Murray, London: pp. $605-607$.

Ahlberg, P. E. 1998. Postcranial stem-tetrapod remains from the Devonian of Scat Craig, Morayshire, Scotland. - Zoological Journal of the Linnean Society 122: 99-141.

Ahlberg, P. E. \& Clack, J. A. 1998. Lower jaws, lower tetrapods - a review based on the Devonian genus Acanthostega. - Transactions of the Royal Society of Edinburgh: Earth Sciences 89: 1146.

Ahlberg, P. E., Lukševičs, E. \& Lebedev, O. 1994. The first tetrapod finds from the Devonian (Upper Famennian) of Latvia. - Philosophical Transactions of the Royal Society of London B 343: $303-$ 328.

Ahlberg, P. E., Clack, J. A., Lukševičs, E., Blom, H. \& Zupiņš, I. 2008. Ventastega curonica and the origin of tetrapod morphology. - Nature 453: 1199-1204.

Anderson, J. S. 2002. Use of well-known names in phylogenetic nomenclature: A reply to Laurin. - Systematic Biology 51: 822827.

Bystrow, A. P. 1935. Morphologische Untersuchungen der Deckknochen des Schädels der Stegocephalen. 1. Mitteilung. Schädel der Stegocephalen. - Acta Zoologica (Stockholm) 16: 65-141.

Clack, J. A. 2002a. Gaining ground. The origin and evolution of tetrapods. Indiana University Press, Bloomington and Indianapolis.

Clack, J. A. 2002b. The dermal skull roof of Acanthostega gunnari, an early tetrapod from the Late Devonian. - Transactions of the Royal Society of Edinburgh: Earth Sciences 93: 17-33.

Clack, J. A. 2003. A revised reconstruction of the dermal skull roof of Acanthostega gunnari, an early tetrapod from the Late Devonian. - Transactions of the Royal Society of Edinburgh: Earth Sciences 93: 163-165.

Coates, M. I. \& Clack, J. A. 1995. Romer's gap: tetrapod origins and terrestriality. - Bulletin du Muséum National d'Histoire Naturelle 17: $373-388$. 
Daeschler, E. B., Shubin, N. H. \& Jenkins, F. A. Jr. 2006. A Devonian tetrapod-like fish and the evolution of the tetrapod body plan. Nature 440: 757-763.

Daeschler, E. B., Clack, J. A. \& Shubin, N. H. 2009. Late Devonian tetrapod remains from Red Hill, Pennsylvania, USA: how much diversity? - Acta Zoologica (Stockholm) 90 (Issue s1): 306-317.

Godfrey, S. J. 1989. The postcranial skeletal anatomy of the Carboniferous tetrapod Greererpeton burkemorani Romer 1969. - Philosophical Transactions of the Royal Society of London B 323: 75133.

Gross, W. 1933. Die Fische des baltischen Devons. - Palaeontographica A 69: 1-74.

Gross, W. 1941. Über den Unterkiefer einiger devonischer Crossopterygier. - Abhandlungen der Preußischen Akademie der Wissenschaften 1941: 1-51.

Gross, W. 1947. Die Agnathen und Acanthodier des obersilurischen Beyrichienenkalks. - Palaeontographica A 96: 91-161.

Jarvik, E. 1944. On the dermal bones, sensory canals and pit-lines of the skull in Eusthenopteron foordi Whiteaves, with some remarks on E. säve-söderberghi Jarvik. - Kungliga Svenska Vetenskapsakademiens Handlingar (3) 21: 1-48.

Jarvik, E. 1972. Middle and Upper Devonian Porolepiformes from East Greenland with special reference to Glyptolepis groenlandica n. sp. - Meddelelser om Grønland 187: 1-307.

Jarvik, E. 1996. The Devonian tetrapod Ichthyostega. - Fossils and Strata 40: 1-213.

Krupina, N. I. 1980. Novyy rod dipnoy iz famena tsentralnogo devonskogo polya. - Paleontologicheskiy Zhurnal 1980 (3): 140-143.

Laurin, M. \& Anderson, J. S. 2004. Meaning of the name Tetrapoda in the scientific literature: an exchange. - Systematic Biology 53: 68-80.

Lebedev, O. \& Clack, J. A. 1993. Upper Devonian tetrapods from Andreyevka, Tula Region, Russia. - Palaeontology 36: 721-734.

Lukševičs, E. 1991. Bothriolepids of the Ketleri Beds of the Upper Devonian of Latvia (Pisces, Placodermi). - Daba un muzejs 3: 38-50 [In Russian].
Lukševičs, E. 2001. Bothriolepid antiarchs (Vertebrata, Placodermi) from the Devonian of the north-western part of the East European Platform. - Geodiversitas 23: 489-609.

Lukševičs, E. \& Zupinsš, I. 2004. Sedimentology, fauna and taphonomy of the Pavāri site, Late Devonian of Latvia. - Acta Universitatis Latviensis 679: 99-119.

Lyarskaja, L. A. \& Savvaitova, L. S. 1974. Structure and ichthyofauna of the Ketleri formation of Latvia. In Afanasyev, B. L., Volkolakov, F. K., Kuršs, V. M., Lunsh, A. Y., Sorokin, V. S. \& Ulst, R. Z. (eds). Regionalnaya geologia Pribaltiki. Zinatne, Riga: pp. 90106

Säve-Söderbergh, G. 1932. Preliminary note on Devonian stegocephalians from East Greenland. - Meddelelser om Grønland 94: 1107

Schultze, H.-P. 1980. Crossopterygier-Schuppen aus dem obersten Oberdevon Lettlands (Osteichthyes, Pisces). - Neues Jahrbuch für Geologie und Paläontologie, Monatshefte 1985: 215-228.

Smithson, T. R. 1982. The cranial morphology of Greererpeton burkemorani Romer (Amphibia: Temnospondyli). - Zoological Journal of the Linnean Society 76: 29-90.

Vorobyeva, E. I. 1962. Rhizodont crossopterygian fishes of the Main Devonian Field of the USSR. - Trudy Palaeontologicheskogo Instituta 94: 1-139 [In Russian].

Vorobyeva, E. I. 1975. An osteolepid crossopterygian from the Ketleri Formation of Latvia. In Grigelis A. A. (ed.). Fauna and Stratigraphy of the Palaeozoic and Mesozoic of Baltics and Byelorussia. Mintis, Vilnius: pp. 233-237.

Vorobyeva, E. I. \& Schultze, H.-P. 1991. Description and systematics of panderichthyid fishes with comments on their relationship to tetrapods. In Schultze, H.-P. \& Trueb, L. (eds). Origins of higher groups of tetrapods. Comstock Publishing Associates, Ithaca: pp. 68-109.

Witzmann, F., Scholz, H., Müller, J. \& Kardjilov, N. In press. Sculpture and vascularization of dermal bones, and the implications for the physiology of basal tetrapods. - Zoological Journal of the Linnean Society. 